\title{
Last Orders
}

David Wheeler: Of course, conceptually any problem in Computer Science can be solved by adding another level of indirection. But then there is performance to consider ... 